\title{
ALIEN COCCINELLIDAE (LADYBIRDS) IN SOCHI NATIONAL PARK AND ITS VICINITY, RUSSIA
}

\author{
Marina Ja. Orlova-Bienkowskaja ${ }^{1}$, Andrzej O. Bieńkowski \\ ${ }^{1}$ Vavilov Institute of General Genetics, Russia \\ ${ }^{2}$ A.N. Severtsov Institute of Ecology and Evolution, Russia \\ e-mail:marinaorlben@yandex.ru
}

Received: 03.08.2017

\begin{abstract}
About 20 alien species of Coccinellidae were released for biological control of pests in the Caucasus. Some of them were reported to be established, but no monitoring of their populations was conducted. So the current state of the populations is unknown. In particular, it was unknown what alien ladybirds occur in Sochi National Park. Survey of Coccinellidae in Sochi National Park and the city of Sochi in 2013, 2016 and 2017 has revealed that the following alien ladybirds occur in the region: Harmonia axyridis, Cryptolaemus montrouzieri, Serangium montazerii and Lindorus lophantae. Harmonia axyridis is an Asian species, which has recently become a global invader. It is a top-predator which has caused a decline of ladybirds in many regions of the world. In 2012 the first established population of this species was found in the Caucasus, namely in Sochi. Now H. axyridis has spread along the whole Black Sea coast of the Caucasus and has become abundant in the region. It is abundant not only in the city of Sochi, but also in the mountain forests of Sochi National Park. It could potentially have a serious impact on native ecosystems, especially on ladybirds. Probably the current population of $H$. axyridis in the Caucasus has appeared as a result of spread from Western Europe and releases of specimens for biocontrol. Cryptolaemus montrouzieri and Lindorus lophantae introduced from Australia and Serangium montazerii introduced from India have been found only in the city of Sochi and are not abundant. Probably they do not affect the ecosystems of Sochi National Park now. But the monitoring of populations of these alien species is necessary, since established populations exist in the region.
\end{abstract}

Key words: alien species, beetles, Coccinellidae, ladybirds

\section{Introduction}

Sochi National Park is situated near the city of Sochi in the Western Caucasus at the Black Sea Shore. The city of Sochi is the largest and one of the oldest Russian resorts. It occupies the narrow band along the sea coast and the lower parts of river valleys. Urban plantations consist mainly of nonnative plants introduced from other regions. The national park is directly adjacent to the city and occupies the nearest mountains covered with forest. The climate in the region is humid subtropical with a warm rainy winter and a sunny summer. The average annual temperature is $+14.2^{\circ} \mathrm{C}$. The average annual precipitation is $1703 \mathrm{~mm}$. The coldest months in the city are January and February with an average temperature of $+6.0^{\circ} \mathrm{C}$. The warmest month is August, its average daily temperature is $+23.6^{\circ} \mathrm{C}$.

This region is especially prone to insect invasions because the mild climate promotes the establishment of alien species and because alien insects are often introduced there unintentionally (with imported planting material) or intentionally (for biological control of pests) (Maslyakov, Izhevsky, 2011). A number of alien insects have established not only in the city, but also in the National Park. It is known that biological invasions in general and invasions of insects in particular are a serious threat to biodiversity (Kenis \& Branco, 2010). So the penetration of alien species to the national park poses a threat for biodiversity in natural ecosystems.

A number of species of alien Coccinellidae have been released in the Caucasus for biological control of pests: Harmonia axyridis (Pallas, 1773), H. conformis (Boisduval, 1835), H. dimidiata (Fabricius, 1781), Cryptolaemus montrouzieri Mulsant, 1853, Serangium montazerii Ftirsch, 1995, S. lygaeum Iablokoff-Khnzorian, 1972, Lindorus lophantae (Blaisdell, 1892), Rodolia cardinalis (Mulsant, 1850), R. rufopilosa Mulsant, 1850, Chilocorus bijugus Mulsant, 1853, C. inornatus Weise, 1887, C. rubidus Hope, 1831, C. kuwanae Silvestři, 1909, C. geminus Zaslavskij, 1962, Nephus reunioni (Fürsch, 1974) and Aiolocaria hexaspilota (Hope, 1831) (Iablokoff-Khnzorian, 1983; Kuznetsov, 1988; Izevsky, 1990). At least six of these species were reported to form established populations in the Caucasus: Harmonia axyridis, Cryptolaemus montrouzieri, Serangium montazerii, Lindorus lophantae, Rodolia cardinalis and Chilocorus bijugus (Izevsky, 1990; Belyakova \& Polikarpova, 2012). But the information about the current state of these populations is insufficient. It 
is known that Harmonia axyridis and Cryptolaemus montrouzieri now occur in Sochi, but it was unknown, if other alien species occur in the region.

We have made a survey of Coccinellidae in the city of Sochi and Sochi National Park to reveal what alien species occur there now and to assess the current state of their populations and possible impact on the native biodiversity.

\section{Material and Methods}

We surveyed the city of Sochi and Sochi National Park for Coccinellidae in May 2013, May 2016 and June 2017. The beetles were collected by hand on trees, shrubs and grasses and also by sweep-netting of grasses and shaking of branches both in daytime and at night. About 800 specimens of 24 species were collected including specimens of four alien species.

\section{Results and Discussion}

Harmonia axyridis (Pallas, 1773) (Fig. 1)

Material. About 100 specimens (imagines, larvae and pupae) collected in Adler, Veseloe, RosaKhutor, Abazinka, Sochi, Semenovka, Monastyr, Razdolnoe and Krasnaya Polyana during 1-11 May 2013; about 100 specimens (imagines, larvae and pupae) collected in Adler, Sochi and Uch-Dere during 16-24 May 2016; about 100 specimens (imagines, larvae and pupae) collected in Imeretian Resort, Khosta, Matsesta and Sochi during 2-19 June 2017.

Biology. Polyphagous, mainly entomophagous species, sometimes feeding on ripe fruits (Roy et al., 2016). We collected this species in urban plantations and in native biotopes in the mountains of Sochi National Park. In the city specimens were found on Rosa, Ficus, Ligustrum, Nerium, Hibiscus, Spiraea, Lysimachia, Rubus. In mountains $H$. axyridis was abundant in the mountain forests on Alnus and other trees and along the rivers on Salix.

Native range. Asia: Siberia, Far East, the north-east of Kazakhstan, Mongolia, China, North Korea, South Korea, Japan, and the north of Vietnam (Orlova-Bienkowskaja et al., 2015).

Invasive range. This ladybird was successfully used for biological control of aphids and other pests all over the world for about 100 years. In the USA it was released since 1916, in the USSR - since 1927 (Georgia, Ukraine, Belarus, Kazakhstan), in Western Europe - since 1982 (Brown et al., 2011). Releases of Harmonia axyridis reared in laboratory were regarded as an effective and ecologically safe method of pest control. Released specimens destroyed agricultural and forest pests and then died. No established populations were found for a long time. But about 20 years ago the situation changed dramatically. Established populations began to appear all over the world. Outside its native range $H$. axyridis has established in some countries of Asia, in North America, South America, Africa and Europe. After establishment in Western Europe $H$. axyridis began to spread quickly. In many European countries it has become a very abundant, dominant species (Brown et al., 2011). The propagation of $H$. axyridis in Europe caused a number of negative ecological consequences. In particular, $H$. axyridis caused a decline of native ladybirds in some regions (Roy et al., 2016). Harmonia axyridis as a top predator with a wide diet range. Negative effects of $H$. axyridis on other ladybird species are likely to be the result of a complex range of interactions and processes including resource competition and predation of larvae of other species.

History of introduction to the Caucasus. Harmonia axyridis was widely used for biological control of Aphidae and other pests in the Caucasus since 1927. In the 1980-s more than 107,000 of specimens brought from the Far East were released in Georgia (Kuznetsov, 1988). But in spite of massive releases, no established populations were found before the $21^{\text {st }}$ century. In 2002-2011 individual specimens were found in different regions of the Caucasus: Adygea (Ukrainsky \& Shapovalov, 2010), south-west of Krasnodar Region (Ukrainsky, 2013), eastern Georgia (Merkviladze \& Kvavadze, 2002), and Abkhazia (Korotyaev, 2015b). In 2012 an established population was found in Sochi (Mogilevich, 2012). Since then $H$. axyridis began to spread in the region quickly. Now it has become an abundant species all over the Black Sea coast of the Caucasus and in adjacent regions: Stavropol region (Korotyaev, 2015b), Krasnodar region (Korotyaev, 2015b), Kabardino-Balkaria (Orlova-Bienkowskaja \& Mogilevich, 2016), Daghestan (Iljina \& Gasanova, 2015), Georgia (Korotyaev, 2015a) and Abkhazia (Orlova-Bienkowskaja, 2014). Probably the current population of the species in the Caucasus has appeared as a result of spread from Western Europe and releases of specimens for biocontrol.

Current state of population. The established population of $H$. axyridis in Sochi is young, probably younger than ten years. But in spite of this the species is abundant both in the city and in native communities of Sochi National Park. It poses a potential threat to biodiversity of native insects, especially ladybirds. 
Cryptolaemus montrouzieri Mulsant, 1853 (Fig. 2)

Material. Sochi, Arboretum, on Nerium oleander, 10.5.2013: 1 adult; Sochi, in the street, on Nerium oleander, 17.5.2016, leg. Bienkowski, 1 specimen.

Biology. Predator of coccids (Izevsky, 1990). In Sochi occurs on oleanders.

Native range. East Australia and New Caledonia. The species occurs only in the coastal region with a warm stable climate, where the temperature does not fall below $17^{\circ} \mathrm{C}$ (Izevsky, 1990).

Invasive range. Introduced to New Zealand, Europe, Asia, Africa, North and South America. In Europe it was released many times since 1908 and established in Italy, Spain, France, Portugal, Albania, Greece, Czech Republic, Georgia (Kováŕ, 2007; Roy \& Migeon, 2010) and the south of European Russia: Sochi (Belyakova \& Polikarpova, 2012).

History of introduction to the Caucasus. Cryptolaemus montrouzieri has been released in different regions of the Caucasus many times since 1930 s to the present. It was regularly used for biological control of Pseudococcidae and Coccidae on plantations of tea, grapes, citrus plants and ornamental plants (Belyakova \& Polikarpova, 2012). But no established populations were recorded for a long time (Kuznetsov, 1988). So Cryptolaemus montrouzieri was kept in the laboratory culture and released by method of seasonal colonisation. In particular, it was released by this method in Sochi. In 2010 breeding of $C$. montrouzieri was detected in Sochi. Then in 2011 and 2012 imagines, larvae and pupae were abundant on Nerium oleander infested by Coccidae in Sochi and Sukhum (Belyakova \& Polikarpova, 2012). Experiments carried out by Belyakova \& Polikarpova (2012) have shown that the population of C. montrouzieri in Sochi is cold-resistant, and beetles are able to survive winter.

Current state of population. According to our observations, $C$. montrouzieri occurred in the city, but was not abundant in 2013 and 2016, although there were many Nerium oleander infested with coccids in Sochi. No specimens of C. montrouzieri have been detected outside the city yet. Obviously, this species does not affect the ecosystems of Sochi National Park now. But since the species is established in the region, the monitoring of its population is necessary.
Serangium montazerii Ftirsch, 1995 (Fig. 3, 4)

Material. Sochi, near the railway station, collected by shaking of branches of trees and shrubs in the nighttime, 10.6.2017: leg. OrlovaBienkowskaja, 1 specimen.

Note. The species was previously misidentified as Serangium parcesetosum Sicard, 1929 (Poorani, 1998).

Biology. Predator of whiteflies, in particular Dialeurodes citri and Bemisia tabaci (Roy \& Migeon, 2010).

Native range. India, Pakistan, Syria.

Invasive range. It is established in Israel, France and Georgia (Poorani, 1998; Kováŕ, 2007) as well as in Sochi (Izevsky, 1990).

History of introduction to the Caucasus. Serangium montazerii was released in 1973 in Georgia, Abkhazia, Azerbaijan and south Russia (Sochi) to control Dialeurodes citri (Aleyrodidae), established and began to spread spontaneously. The local populations were re-novated by additional releases from laboratory culture (Izevsky, 1990).

Current state of population. There was no information about the state of population after the 1970-s. It was unknown, whether the population still existed or died out. Our observations have shown that $S$. montazerii still occurs on the Black Sea shore of the Caucasus. But this species is not abundant and obviously does not affect ecosystems of Sochi National Park.

Lindorus lophantae (Blaisdell, 1892) (Fig. 5)

(=Rhyzobius lophanthae Blaisdell, 1892)

Material. Sochi, on shrubs in the street, 17.05.2016: 2 imagines. Sochi, shaking of shrubs in the street 13.06.2017: leg. Orlova-Bienkowskaja, 1 imago.

Biology. Predator of scale insects (Diaspididae). Native range. Australia (Rubtsov, 1952).

Invasive range. Russia (Sochi and Crimea), Albania, Croatia, France, Greece, Italy, Spain, Yugoslavia, United Kingdom, Georgia, Algeria, the Canary Islands, Morocco, Madeira, Tunisia, Iran, Turkey, India as well in Nearctic and Neotropical Regions (Kovář, 2007; Roy \& Migeon, 2010).

History of introduction to the Caucasus. It was released for control of Diaspididae in 1948 in Georgia. An established population was detected in Georgia. The whole population of L. lophantae in the Caucasus derives from laboratory culture, established from just one pair of insects collected in Italy near Rome (Rubtsov, 1952). 


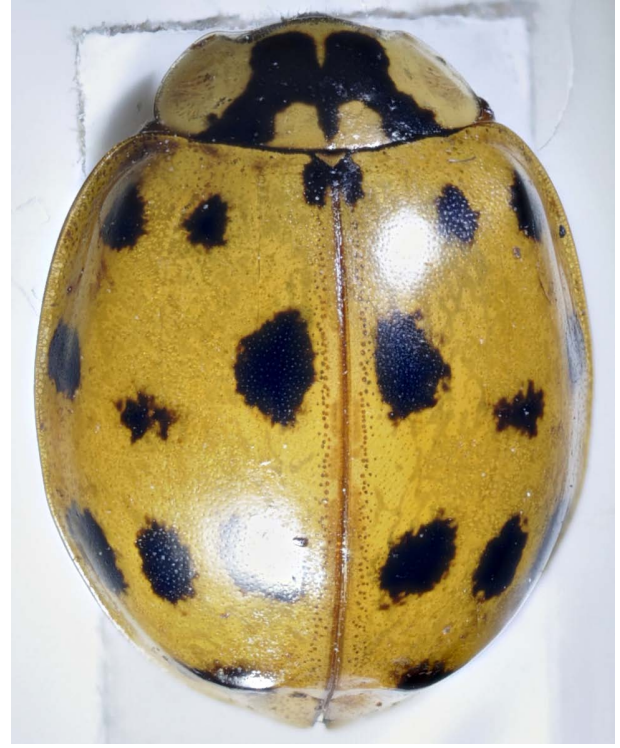

Fig. 1. Harmonia axyridis.

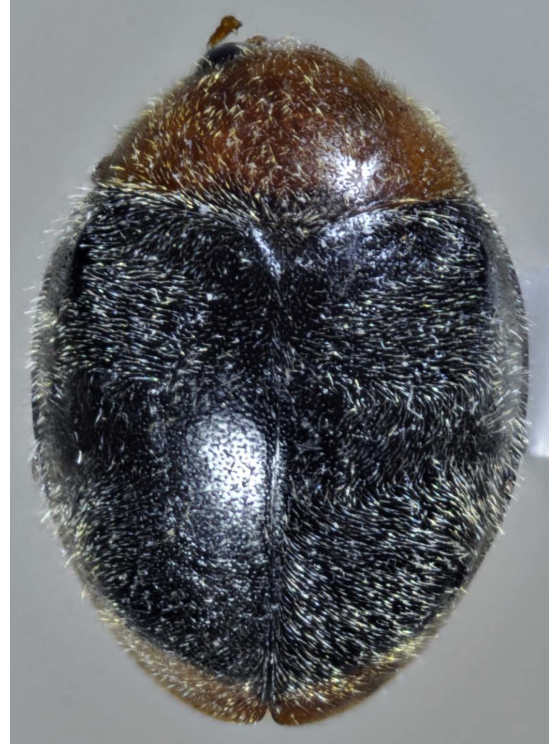

Fig. 2. Cryptolaemus montrouzieri.

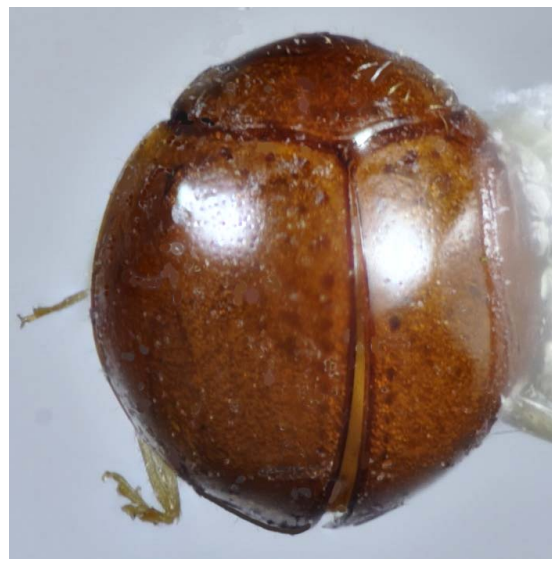

Fig. 3. Serangium montazerii, dorsal view.

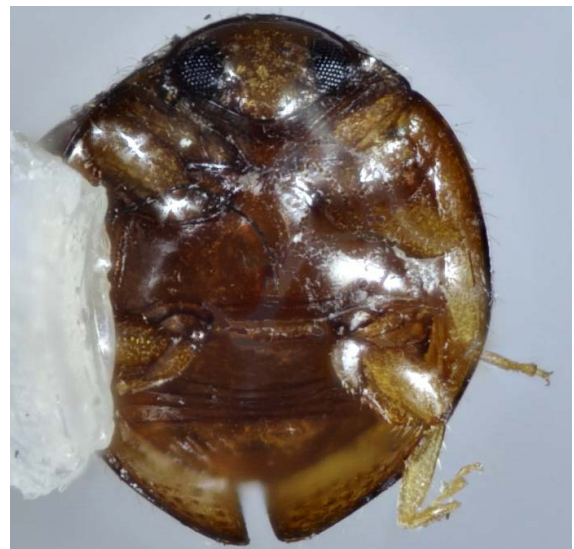

Fig. 4. Serangium montazerii, ventral view.

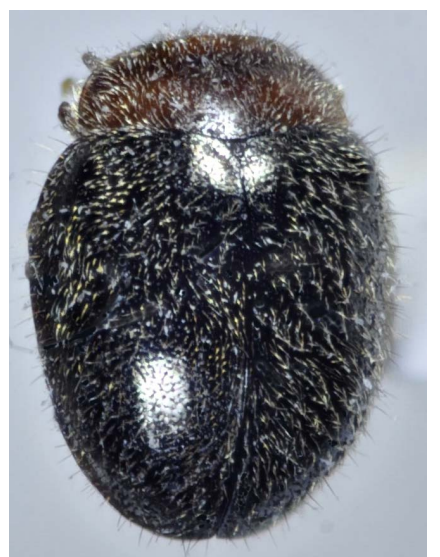

Fig. 5. Lindorus lophantae.
Current state of population. Our observations have shown that the population of Lindorus lophantae still occurs in Sochi. But there are no evidences of penetration of this species outside the city, to the native communities of Sochi National Park.

At least two other coccinellids have established in the Caucasus as a result of intentional introduction: Chilocorus bijugus Mulsant, 1853 and Rodolia cardinalis (Mulsant, 1850) (Izevsky, 1990). Chilocorus bijugus occurs in Georgia in the vicinity of Batumi (Izevsky, 1990). There are no evidences of its occurrence in Russia. Rodolia cardinalis was widely used for control of Icerya purchasi (Maskell, 1878) on citrus plantations in Sochi. An established population existed in Sochi previously, but no specimens have been found in the last 20 years because of the liquidation of citrus plantations (personal communication by V.I. Filippov). Nevertheless, Icerya purchasi still occurs in Sochi on Acacia dealbata (our own observations in 2016). Therefore, it is not excluded that a small population of $R$. cardinalis still exists in Sochi.

\section{Conclusions}

The following alien species of ladybirds occur in the vicinity of Sochi now: Harmonia axyridis, Cryptolaemus montrouzieri, Serangium montazerii and Lindorus lophantae. The first species does not only occur in the city, but is also abundant in the mountains and could potentially have a serious impact on ecosystems of Sochi National Park. Three other species have been detected so far only in the city and probably do not affect the native ecosystems yet. Monitoring of the populations of all these alien species is necessary.

\section{Acknowledgements}

The work by M. Ja. Orlova-Bienkowskaja was supported by the Russian Science Foundation grant No. 16-1600079. The work by A. O. Bieńkowski was supported by the 
Russian Science Foundation, Project No 16-14-10031. We are grateful to V.I. Filippov (Sochi) for valuable information.

\section{References}

Belyakova N.A., Polikarpova Yu.B. 2012. Harmonia axyridis and Cryptolaemus montrouzieri acclimatization at the Black Sea Coast of the Caucasus. Plant Protection News 4: 43-48. [In Russian]

Brown P.M.J., Thomas C., Lombaert E., Jeffries D.L., Estoup A., Lawson Handley L.J. 2011. The global spread of Harmonia axyridis: distribution, dispersal and routes of invasion. Biocontrol 56(4): 623-641. DOI: 10.1007/s10526-011-9379-1

Iljina E.V., Gasanova N.M.-S. 2015. Invasive species of insects in Daghestan. In: Biodiversity and rational use of natural resources: proceedings of III All-Russian scientific-practic conference with international participation (Makhachkala, 27 March 2015). Makhachkala: Publishing House of Daghestan State Pedagogical University. P. 78-81. [In Russian]

Iablokoff-Khnzorian S.M. 1983. Review of the coccinellid fauna of the USSR. Academy of Sciences of Armenian SSR Institute of zoology Zoological Papers 19: 94-161. [In Russian]

Izevsky S.S. 1990. Introduction and application of entomophages. Moscow: Agropromizdat 223 p. [In Russian]

Kenis M., Branco M. 2010. Impact of alien terrestrial arthropods in Europe. Chapter 5. BioRisk 4: 51. DOI: 10.3897/biorisk.4.42

Korotyaev B.A. 2015a. On the distribution dynamics of some beetles (Coleoptera: Coccinellidae, Bruchidae, Curculionidae) in the plains of the Northwestern Caucasus, Russia. Entomological Review 95(1): 137-140. DOI: 10.1134/S0013873815010157

Korotyaev B.A. 2015b. On the high abundance of the harlequin lady beetle Harmonia axyridis (Pall.) (Coleoptera, Coccinellidae) in the plains of Northwestern Caucasus, Russia. Entomological Review 95(9): 1317-1319. DOI: 10.1134/S0013873815090195

Kováŕ I. 2007. Coccinellidae. In: I. Löbl, A. Smetana (Eds.): Catalogue of Palaearctic Coleoptera. Vol. 4. Stenstrup: Apollo Books. P. 568-631.

Kuznetsov V.N. 1988. Far Eastern coccinellids in the Transcaucasia. Zashchita rasteniy 5: 19. [In Russian]

Maslyakov V.Yu., Izhevsky S.S. 2011. Alien Phytophagous Insects Invasions in the European Part of Russia. Moscow: IGRAS. 289 p. [In Russian]

Merkviladze M.Sh., Kvavadze E.Sh. 2002. List of ladybirds (Coleoptera, Coccinellidae) of Georgia. Proceedings of the Institute of Zoology 21: 149-155.

Mogilevich T.A. 2012. My experiments with the ladybird Harmonia axyridis. In: Beetles and coleopterologists. Available from: http://www.zin.ru/Animalia/Coleoptera/rus/mogilev1.htm.
Orlova-Bienkowskaja M.Ja. 2014. The Outbreak of Harlequin Ladybird Harmonia axyridis (Pallas, 1773) (Coleoptera, Coccinellidae) in the Caucasus and Possible Sources of Invasion. Russian Journal of Biological Invasions 5(4): 275-281. DOI: 10.1134/ S2075111714040055

Orlova-Bienkowskaja M.Ja., Mogilevich T.A. 2016. The first record of Asian ladybird Harmonia axyridis (Pallas, 1773) (Coleoptera: Coccinellidae) in KabardinoBalkaria and the history of the expansion of this alien species in the Caucasus and south of European Russia in 2002-2015. Caucasian Entomological Bulletin 12(1): 93-98. [In Russian]

Orlova-Bienkowskaja M.J., Ukrainsky A.S., Brown P.M.J. 2015. Harmonia axyridis (Coleoptera: Coccinellidae) in Asia: a re-examination of the native range and invasion to southeastern Kazakhstan and Kyrgyzstan. Biological Invasions 17(7): 1941-1948. DOI: 10.1007/ s10530-015-0848-9

Poorani J. 1998. A new species of Serangium Blackburn (Coleoptera: CoccineIIidae), with a key to species, from India. Journal of Biological Control 12(1): 55-61.

Roy H., Migeon A. 2010. Ladybeetles (Coccinellidae) chapter 8.4. BioRisk 4(1): 293-313. DOI: 10.3897/biorisk.4.49

Roy H.E., Brown P.M.J., Adriaens T., Berkvens N., Borges I., Clusella-Trullas S., Comont R.F., De Clercq P., Eschen R., Estoup A., Evans E.W., Facon B., Gardiner M.M., Gil A., Grez A.A., Guillemaud Th., Haelewaters D., Herz A., Honek A., Howe A.G., Hui C., Hutchison W.D., Kenis M., Koch R.L., Kulfan J., Lawson Handley L., Lombaert E., Loomans A., Losey J., Lukashuk A.O., Maes D., Magro A., Murray K.M., San Martin G., Martinkova Z., Minnaar I.A., Nedved O., Orlova-Bienkowskaja M.J., Osawa N., Rabitsch W., Ravn H.P., Rondoni G., Rorke S.L., Ryndevich S.K., Saethre M.-G., Sloggett J.J., Soares A.O., Stals R., Tinsley M.C., Vandereycken A., van Wielink P., Viglášová S., Zach P., Zakharov I.A., Zaviezo T. Zhao Z. 2016. The harlequin ladybird, Harmonia axyridis: global perspectives on invasion history and ecology. Biological Invasions 18(4): 997-1044. DOI: 10.1007/ s10530-016-1077-6

Rubtsov I.A. 1952. Lindorus, an effective predator of Diaspididae scales. Entomologicheskoe Obozrenie 32(1): 96-106.

Ukrainsky A.S. 2013. The multicoloured Asian lady beetle Harmonia axyridis Pall. (Coleoptera, Coccinellidae) in the North Caucasus. Euroasian Entomological Journal 12(1): 35-38. [In Russian]

Ukrainsky A.S., Shapovalov M.I. 2010. Coccinellidae - Ladybirds. In: A.S. Zamotajlov, N.B. Nikitsky (Eds.): Coleopterous insects (Insecta, Coleoptera) of Republic of Adygheya (annotated catalogue of species) (Fauna conspecta of Adygheya. № 1). Maykop: Adyghei State University. P. 199-201. [In Russian] 


\title{
ЧУЖЕРОДНЫЕ СОССINELLIDAЕ (БОЖЫИ КОРОВКИ) В СОЧИНСКОМ НАЦИОНАЛЬНОМ ПАРКЕ И ЕГО ОКРЕСТНОСТЯХ (РОССИЯ)
}

\author{
М. Я. Орлова-Беньковская ${ }^{1}$, А. О. Беньковский² \\ ${ }^{1}$ Институт общей генетики имени Н.И. Вавилова, Россия \\ ${ }^{2}$ Институт экологии и эволюиии имени А.Н. Севериова, Россия \\ e-mail:marinaorlben@yandex.ru
}

Около 20 чужеродных видов Coccinellidae было выпущено для биологического контроля вредителей на Кавказе. Некоторые из них, как сообщалось, обосновались, но мониторинг их популяций не проводился. Таким образом современное состояние популяций неизвестно. В частности, до сих пор было неизвестно, какие чужеродные божьи коровки встречаются в Сочинском национальном парке. Исследование Coccinellidae в Сочинском национальном парке и городе Сочи в 2013, 2016 и 2017 годах показало, что в регионе присутствуют следующие чужеродные божьи коровки: Harmonia axyridis, Cryptolaemus montrouzieri, Serangium montazerii и Lindorus lophantae. Harmonia axyridis - это азиатский вид, который в последнее время стал инвазионным видом в глобальном масштабе. Это опасный хищник, вызвавший снижение разнообразия божьих коровок во многих регионах мира. В 2012 году первая акклиматизировавшаяся популяция этого вида была обнаружена на Кавказе, а именно в Сочи. В настоящее время H. axyridis распространилась по всему Черноморскому побережью Кавказа и стала многочисленной в регионе. Он многочислен не только в городе Сочи, но и в горных лесах Сочинского национального парка. Этот вид может потенциально оказывать серьезное влияние на природные экосистемы, особенно на божьих коровок. Вероятно, ныне известная популяция H. axyridis на Кавказе появилась в результате проникновения из Западной Европы и выпусков отдельных насекомых для биоконтроля. Cryptolaemus montrouzieri и Lindorus lophantae, проникшие из Австралии, и Serangium montazerii, происходящая из Индии, были обнаружены только в г. Сочи, и в настоящее время немногочисленны. Вероятно, в настоящее время они не оказывают влияния на экосистемы Сочинского национального парка. Но мониторинг популяций этих чужеродных видов необходим, поскольку в регионе присутствуют акклиматизировавшиеся популяции.

Ключевые слова: Coccinellidae, божьи коровки, жесткокрылые, чужеродные виды 